\title{
Hiatal hernia mimicking heart problems
}

\author{
Wolfram Schummer
}

Department of Anaesthesiology and Intensive Care Medicine, Friedrich-Schiller-Universitat Jena Medizinische Fakultat, Jena, Thuringia, Germany

\section{Correspondence to}

DrWolfram Schummer, wolfram.schummer@web.de, cwsm.schummer@gmx.de

Accepted 4 July 2017

\section{DESCRIPTION}

A 73-year-old man presented to the emergency department with symptoms of acute coronary syndrome. Findings on examination were dyspnoea, chest tightness and a burning sensation behind the sternum.

On admission, 3 hours after the onset of symptoms, his 12-lead ECG showed a left bundle branch block. Cardiac enzymes revealed only marginally elevated creatine kinase, aspartate transaminase and lactate dehydrogenase levels; however, troponin I $(<0.04 \mathrm{ng} / \mathrm{mL})$ was increased to 17 and N-terminal prohormone of brain natriuretic peptide (NT-proBNP) to $1472 \mathrm{pg} / \mathrm{mL}$ (73 year normal range: $10-220 \mathrm{pg} / \mathrm{mL}$ ). Though the consulting cardiologist determined coronary angiography to be unnecessary at the time, the patient was promptly sent to the intensive care unit (ICU) for monitoring and for quick intervention, if needed.

At that time, further information was gathered from the patient and his family. Apparently, the symptoms had started during lunch. The patient had experienced these symptoms several times in the preceding months; this time, however, the complaints were extraordinary: chest tightness and dyspnoea increased dramatically in the supine position and decreased while upright. His previous medical history was relevant for obesity $(110 \mathrm{~kg}, 174 \mathrm{~cm})$, non-insulin-dependent diabetes mellitus, hypertension and hyperlipidaemia. Thus, coronary artery disease seemed plausible, as did congestive heart failure. Physical capacity was dramatically limited (eg, the patient was rarely capable of climbing a flight of stairs without pausing). In addition, his wife reported that dyspnoea on exertion had increased progressively in the past few months.

A bedside chest radiograph showed an enlarged cardiac silhouette, mimicking cardiomegaly. However, there also appeared to be a large mass behind the heart, extending beyond the cardiac borders.

To evaluate this case, a CT scan was performed. The scan showed a large retrocardiac mass consistent with a large hiatal hernia and dislocation of the stomach into the chest (figures 1-4).

Concomitantly with these findings, cardiac enzymes except for BNP normalised within 48 hours, suggesting the absence of ongoing coronary ischaemia.

The symptoms were alleviated with gastric suction via a gastric tube. After 48 hours, this

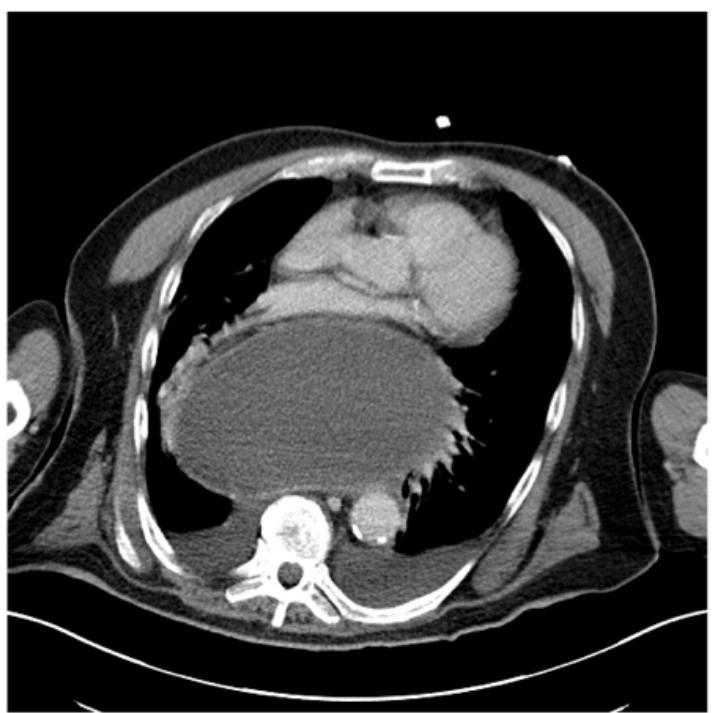

Figure 1 Transverse (horizontal) plane CT: showing a large retrocardiac mass squeezing the left atrium. 
procedure was followed by initiation of an oral diet consisting initially of clear liquids followed by an enteral formula diet.

In tandem, a general surgeon was consulted for his opinion regarding potential risks and benefits of surgical intervention.

Ten days later, the patient underwent transabdominal open repair of his giant hiatal hernia. Surgery consisted of an infradiaphragmatic relocation of the stomach, hernia reduction and crural reapproximation. Postoperatively, the patient was transferred to the ICU to be monitored. The endotracheal tube already had been removed in the operating room. Due to respiratory distress, the patient had to be reintubated and mechanically ventilated on postoperative day 1 . Surgical manipulation in the chest and on the diaphragm, preoperative compression of the lungs, pre-existing pneumonia, obesity and congestive heart failure were assumed to be among the reasons for respiratory deterioration. The surgeon was not enthusiastic about mechanical ventilation due to concerns about the surgical result. The possibility of a 'gentle' mode of ventilation was explored. Accordingly, the patient was treated using differential lung ventilation by two respirators via a double-lumen endotracheal tube, the right lung being ventilated and the left lung being put at rest on a positive end-expiratory pressure level of $10 \mathrm{~cm}$.
Pneumonia was treated with intravenous piperacillin/tazobactam. On postoperative day 4, the patient was successfully extubated and remained stable until discharge from the ICU. One week later, he left the hospital. The last BNP value was $621 \mathrm{pg} / \mathrm{mL}$.

Retrospectively, we concluded that a giant hiatal hernia with intrathoracic dislocation of abdominal contents can mimic acute coronary syndrome clinically, impair physical capacity and possibly increase BNP levels.

Contributors WS was involved in the treatment of the patient and wrote the manuscript.

Competing interests None declared.

Patient consent Obtained.

Provenance and peer review Not commissioned; externally peer reviewed.

(c) BMJ Publishing Group Ltd (unless otherwise stated in the text of the article) 2017. All rights reserved. No commercial use is permitted unless otherwise expressly granted.

\section{REFERENCES}

1 Narala K, Banga S, Hsu M, et al. Hiatal hernia mimicking ST elevation myocardial infarction. Cardiology 2014;129:258-61.

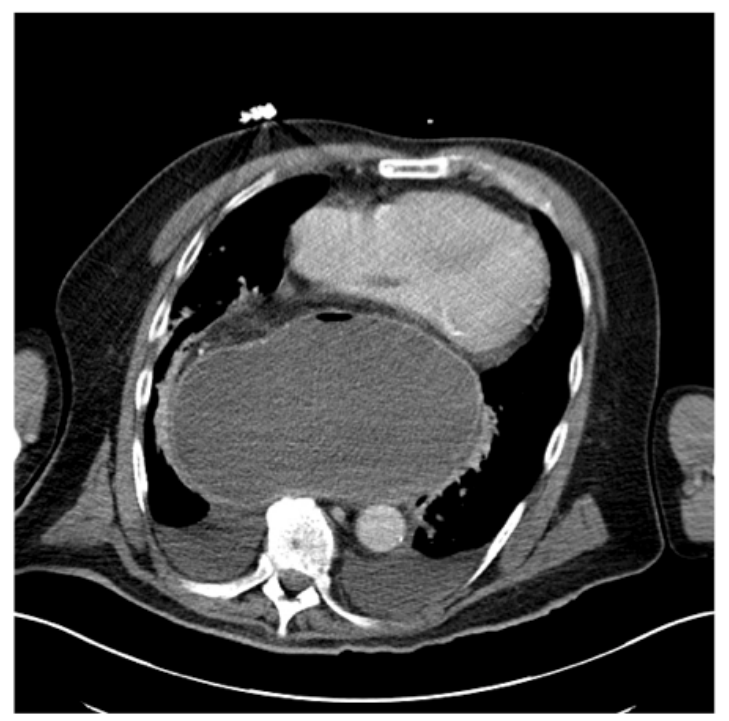

Figure 2 Transverse (horizontal) plane CT: retrocardiac mass displacing heart and lungs. 


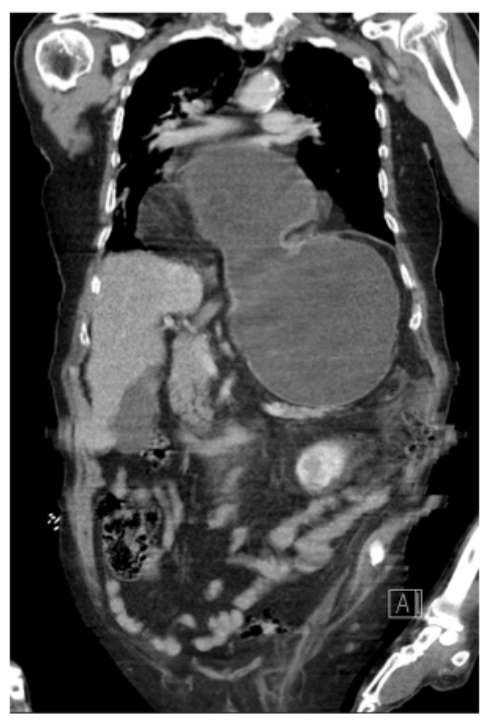

Figure 3 Coronal (frontal) plane CT: intra-abdominal and intrathoracic parts of the stomach with the point of passage through the diaphragm. 


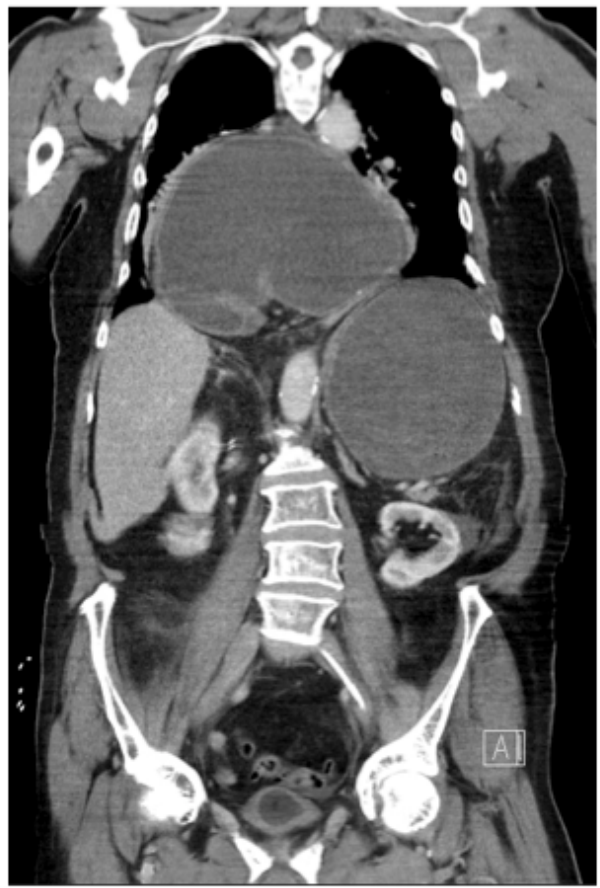

Figure 4 Coronal (frontal) plane CT: vast intra-abdominal and intrathoracic proportions of the stomach with corresponding displacements.

Copyright 2017 BMJ Publishing Group. All rights reserved. For permission to reuse any of this content visit http://group.bmj.com/group/rights-licensing/permissions.

BMJ Case Report Fellows may re-use this article for personal use and teaching without any further permission.

Become a Fellow of BMJ Case Reports today and you can:

- Submit as many cases as you like

- Enjoy fast sympathetic peer review and rapid publication of accepted articles

- Access all the published articles

- Re-use any of the published material for personal use and teaching without further permission

For information on Institutional Fellowships contact consortiasales@bmjgroup.com

Visit casereports.bmj.com for more articles like this and to become a Fellow 


\section{Learning points}

- Diagnosis of acute coronary syndrome is based on clinical presentation, clinical history (including risk factors), a 12-lead ECG, cardiac biomarkers and coronary angiography.

- The 12-lead ECG is the primary avenue of investigation. The presence of new ST-segment elevation indicates that the pain is likely due to myocardial infarction. However, $11 \%$ have a non-diagnostic ECG (bundle branch block and paced rhythm) and $43 \%$ have a normal initial ECG.

- The troponin complex is a sensitive and specific marker of myocardial damage. In myocardial infarction, troponin levels rise about 4 hours after the onset of chest pain in $30 \%-50 \%$ of patients. There is a strong relationship between the peak level of troponin at 12-24hours from the onset of pain and the extent of myocardial damage and clinical outcome.

- B-type natriuretic peptides are markers of myocardial wall stress. Brain natriuretic peptides (BNPs) or $\mathrm{N}$-terminal proBNPs are used for differential diagnosis of acute dyspnoea where normal concentrations make a cardiac cause unlikely.

- However, one must be alert for other causes of cardiac complaints and chest pain. Giant hiatal hernias have been reported to change ECG pattern and rhythm. ${ }^{12}$ Obviously, hiatal hernias may also be the reason for an increase in BNPs. 